Check for updates

Cite this: Mater. Chem. Front., 2019, 3, 1199

Received 18th February 2019, Accepted 17th April 2019

DOI: $10.1039 / \mathrm{c} 9 \mathrm{qm} 00105 \mathrm{k}$

rsc.li/frontiers-materials

\section{Syntheses, crystal structures, chirality and aggregation-induced phosphorescence of stacked binuclear platinum(II) complexes with bridging Salen ligands $\dagger$}

\author{
Lang Qu, Chunbo Li, Guangyu Shen, Fei Gou, Jintong Song, Man Wang, \\ Xuemei Xu, Xiangge Zhou (DD and Haifeng Xiang (D)*
}

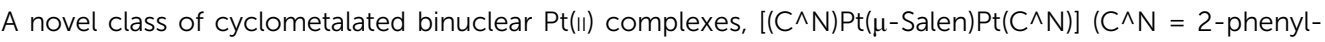
pyridine or benzo[ $h$ ]quinoline, Salen $=N, N^{\prime}$-bis(salicylidene)ethylenediamine), have been synthesized and characterized. Owing to the blockage of intramolecular rotation in the bridging Salen ligands, all the double-layer stacked complexes exhibit strong aggregation-induced phosphorescence with quantum yields up to 0.35 through well-tuned intramolecular Pt-Pt interactions (3.37-4.48 $⿱$ ) and strong multiple intermolecular interactions, such as $\mathrm{H}-\mathrm{H}, \mathrm{C}-\mathrm{H}, \mathrm{O}-\mathrm{H}, \mathrm{Cl}-\mathrm{H}$, and $\mathrm{Pt}-\mathrm{H}$ interactions. Interestingly, if chiral Salen ligands are adopted, it is facile to prepare $(R, R) /(S, S)$ enantiopure $\mathrm{Pt}(\|)$ complexes, which were characterized by X-ray diffraction, circular dichroism spectra and time-dependent density functional theory calculations. This is the first example of stacked binuclear Pt(I) complexes with well-known tetradentate Salen ligands as bis-bidentate-bridging ligands and would render a new structural motif for bridging ligands and chiral binuclear complexes.
\end{abstract}

\section{Introduction}

The class of cyclometalated Pt(II) complexes has been extensively investigated in the past two decades owing to their interesting and rich phosphorescence properties. ${ }^{1-8}$ Unlike other wellknown octahedral phosphorescent $d^{6} \mathrm{Ru}(\mathrm{II})^{9,10}$ and $\operatorname{Ir}(\mathrm{III})^{11,12}$ complexes, $\mathrm{d}^{8} \mathrm{Pt}$ (II) complexes adopt a square-planar geometry with a vacant coordination site at the Pt(II) center, which allows axial substrate-binding interactions and might lead to strong intramolecular and intermolecular interactions consequently. Therefore, $\mathrm{Pt}(\mathrm{II})$ complexes have rich transition states including not only $\left(\pi-\pi^{*}\right)$ intraligand charge transfer $\left({ }^{3}\right.$ ILCT) and $\left(\mathrm{d}-\pi^{*}\right)$ triplet metal-to-ligand charge transfer $\left({ }^{3} \mathrm{MLCT}\right)$ common to normal transition metal complexes, but also metal-metal-toligand charge transfer $\left({ }^{3} \mathrm{MMLCT}\right)$ through strong intramolecular and intermolecular Pt-Pt interactions. Moreover, strong intermolecular Pt-Pt interactions combined with intermolecular $\pi-\pi$ stacking interactions have been widely used to promote molecular self-assembly and supramolecular gelation. ${ }^{13,14}$ On the other hand,

College of Chemistry, Sichuan University, Chengdu, 610041, China.

E-mail: xianghaifeng@scu.edu.cn; Fax: +86 28-8541-2291

$\dagger$ Electronic supplementary information (ESI) available: General, materials, computational details, crystallographic information files (CIF), crystallographic data, absorption, and fluorescence emission data. CCDC 1589703, 1589704, 1589683, 1589684, and 1589685. For ESI and crystallographic data in CIF or other electronic format see DOI: $10.1039 / \mathrm{c} 9 \mathrm{qm} 00105 \mathrm{k}$
$\mathrm{Pt}$ (II) complexes are far more likely to encounter the problem of emission "aggregation-caused quenching" (ACQ), ${ }^{15}$ because they easily form excimers through these strong intermolecular interactions in high concentrations and the solid state. In order to solve the ACQ problem, a lot of effort has been made to develop aggregation-induced emission (AIE) ${ }^{15-18}$ or phosphorescence $(\mathrm{AIP})^{19}$-active materials.

In the literature, there are a lot of phosphorescent stacked binuclear Pt(II) complexes. The cyclometalated or auxiliary ligands of these stacked binuclear $\mathrm{Pt}$ (II) complexes usually are $\mathrm{C}^{\wedge} \mathrm{N},{ }^{20-24} \mathrm{C}^{\wedge} \mathrm{N}^{\wedge} \mathrm{N},{ }^{25,26} \mathrm{~N}^{\wedge} \mathrm{N}^{\wedge} \mathrm{N},{ }^{27-29}$ and $\mathrm{C}^{\wedge} \mathrm{C}^{*}$ (N-heterocyclic carbenes), ${ }^{30,31}$ whose mononuclear Pt(II) complexes are highly emissive in dilute solution. The simple bidentate pyrazolate (pz), ${ }^{21-25,28,31}$ pyridine-2-thiolate (pyt), ${ }^{20}$ bis(diphenylphosphino)methane (dppm), ${ }^{25,26}$ disulfur, $^{29}$ and amidinate ${ }^{30}$ ligands with strong coordination ability are used as bridging ligands. It has been proved that the ${ }^{3}$ MMLCT transition of stacked binuclear $\mathrm{Pt}$ (II) complexes is strongly dependent on the intramolecular Pt-Pt distances (2.8-4.0 $\AA$ ) through the interacting $5 \mathrm{~d}_{z^{2}} \mathrm{Pt}(\mathrm{II})$ orbitals. ${ }^{20-31}$ For example, the transition energy or emission band $\left(\lambda_{\mathrm{em}}\right)$ of binuclear $\left[\left(\mathrm{C}^{\wedge} \mathrm{N}\right) \operatorname{Pt}(\mu-\mathrm{pyt}) \mathrm{Pt}\left(\mathrm{C}^{\wedge} \mathrm{N}\right)\right]$ complexes can be well tuned in the whole region of visible light by the presence of steric bulk at the 3,5-positions of the bridging pz ligands, which in turn alters the Pt-Pt distance within the complex. ${ }^{21,22}$ Our research group has a longstanding interest in the synthesis and optical properties of $N, N^{\prime}$-bis(salicylidene)ethylenediamine (Salen), ${ }^{32-38}$ 
(a)

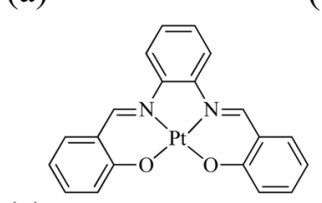

(c)

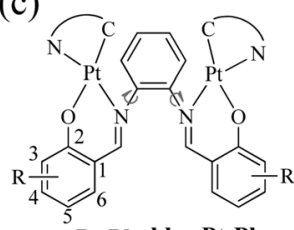

ppy-Pt-Ph bhq-Pt-Ph ppy-Pt-3-Cl-Ph

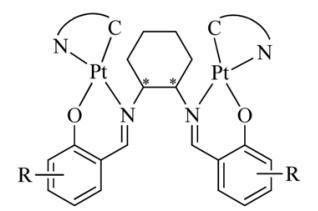

ppy-Pt- $(S, S) \mathrm{Cy}$ ppy-Pt- $(R, R) \mathrm{Cy}$ ppy-Pt-3-F- $(R, R) C y$ ppy-Pt-3-F- $(S, S) C y$ ppy-Pt-3-Cl- $(R, R)$ Cy ppy-Pt-3-Cl- $(S, S) \mathrm{Cy}$

Scheme 1 Reported mononuclear Pt(Salen) complexes (a), reported binuclear $\mathrm{Pt}_{2}\left(\right.$ Salen) 2 complexes (b), and stacked binuclear [( $\left.\mathrm{C}^{\wedge} \mathrm{N}\right) \mathrm{Pt}\left(\mu-\right.$ Salen)Pt$\left(\mathrm{C}^{\wedge} \mathrm{N}\right)$ ] complexes (c) in this work.

a particular class of tetradentate $\mathrm{N}^{\wedge} \mathrm{O}^{\wedge} \mathrm{O}^{\wedge} \mathrm{N}$ chelating bis-Schiff base ligands, and their complexes (Scheme 1a) ${ }^{39,40}$ due to their facile preparation, good stabilities, biological activities, rich photophysical properties, high emission quantum yields $(\Phi)$, and wide applications in catalysts, ${ }^{41,42}$ DNA cleavage,,${ }^{43,44}$ optical and magnetic materials, ${ }^{45,46}$ supramolecular materials, ${ }^{47,48}$ cell imaging, ${ }^{49,50}$ and organic light-emitting diodes. ${ }^{51-55}$ When Salen ligands react with $\mathrm{Pt}^{2+}$ ions directly, they can act as tetradentate chelating reagents to form phosphorescent mononuclear Pt(Salen) complexes ( $\Phi$ up to 0.27 in dilute MeCN) (Scheme 1a). ${ }^{52-55}$ Moreover, Komiya et al. ${ }^{56}$ reported some separate binuclear $\mathrm{Pt}_{2}(\mathrm{Salen})_{2}$ complexes (Scheme 1b) which are linked by non-conjugated long heptyl and consequently exhibit AIP through intermolecular Pt-Pt interactions rather than intramolecular Pt-Pt interactions. Huang's $\mathrm{s}^{57}$ and our group ${ }^{58}$ recently demonstrated that mononuclear $\left[\left(\mathrm{C}^{\wedge} \mathrm{N}\right) \mathrm{Pt}\left(\mathrm{N}^{\wedge} \mathrm{O}\right)\right]$ complexes $(\Phi$ up to 0.38 in the crystal state) and propeller-type binuclear $\left[\left(\mathrm{C}^{\wedge} \mathrm{N}\right) \operatorname{Pt}(\mu-\mathrm{SA}) \mathrm{Pt}\left(\mathrm{C}^{\wedge} \mathrm{N}\right)\right](\mathrm{SA}=$ salicylaldehyde azine) complexes ( $\Phi$ up to 0.14 in the solid state) have neither intramolecular nor intermolecular Pt-Pt interactions but show strong AIP as well. Herein we present a series of novel neutral and chiral binuclear Salen-bridged $\left[\left(\mathrm{C}^{\wedge} \mathrm{N}\right) \mathrm{Pt}(\mu-\right.$ Salen $\left.) \operatorname{Pt}\left(\mathrm{C}^{\wedge} \mathrm{N}\right)\right]$ complexes $\left(\mathrm{C}^{\wedge} \mathrm{N}\right.$ : $\mathrm{ppy}=2$-phenylpyridine and $\mathrm{bhq}=$ benzo[ $h]$ quinolone; Salen: $\mathrm{Ph}=N, N^{\prime}$-bis(salicylidene)-1,2-phenylenediamine, $\mathrm{Cy}=N, N^{\prime}$-bis(salicylidene)-1,2-cyclohexanediamine, and $\operatorname{diPh}=N, N^{\prime}$-bis(salicylidene)-1,2-diphenylethane-1,2-diamine) (Scheme 1c). Through the blockage of the intramolecular rotation of the bridging Salen ligands and well-tuned intramolecular Pt-Pt interactions (3.37-4.48 $\AA$ ), these double-layer stacked complexes exhibit strong AIP ( $\Phi$ up to 0.35 in the solid state). To the best of our knowledge, they are the first examples of stacked binuclear
Pt(II) complexes with well-known tetradentate Salen ligands as bis-bidentate-bridging ligands.

\section{Results and discussion}

\section{Synthesis and characterization}

All bridging Salen ligands were reasonably easy to synthesize by the condensation of a primary diamine with 2 equivalents of salicylaldehyde precursor in ethanol under reflux conditions according to our previous reports. ${ }^{34,38}$ The reason why we chose auxiliary $\mathrm{C}^{\wedge} \mathrm{N}$ ligands is that their $\mathrm{Pt}(\mathrm{II})$ complexes are highly phosphorescent and $\left[\left(\mathrm{C}^{\wedge} \mathrm{N}\right) \mathrm{Pt}(\mu-\mathrm{Cl})_{2} \mathrm{Pt}\left(\mathrm{C}^{\wedge} \mathrm{N}\right)\right]$ (Scheme 2) is an ideal precursor to prepare bis-cyclometalated $\mathrm{Pt}(\mathrm{II})$ complexes. ${ }^{23,59}$ The bridging Salen ligands were adopted due to their simple, chiral, and rotatable structures (Scheme 1c) that would help to achieve chiral and AIE properties for some special applications in chiral recognition $^{60,61}$ and circularly polarized luminescence $(\mathrm{CPL})^{62,63}$ The binuclear Pt(II) complexes were straightforwardly synthesized according to Scheme 2 . The complexes with conjugated $\mu$-Ph are weakly soluble in $\mathrm{CH}_{2} \mathrm{Cl}_{2}$, benzene, and THF but not soluble in water, ether, ethanol, and hexane, and thus we didn't obtain their nuclear magnetic resonance (NMR) spectra. The complexes with non-conjugated $\mu$-Cy or $\mu$-diPh have much better solubility in $\mathrm{CH}_{2} \mathrm{Cl}_{2}$, benzene, and THF.

\section{Absorption and AIP properties}

The room-temperature UV/visible absorption and AIP properties of the Pt(II) complexes are listed in Table 1, Fig. 1-5 and Fig. S1-S12 (ESI $\dagger$ ). These Pt(II) complexes have similar absorption spectra, even though they bear different bridging ligands and $\mathrm{C}^{\wedge} \mathrm{N}$ auxiliary ligands. To gain insight into the nature of the excited states and transitions, density functional theory (DFT) and time-dependentDFT (TD-DFT) calculations were carried out for ppy-Pt-3-Cl-Ph and ppy-Pt- $(\boldsymbol{S}, \boldsymbol{S})$ Cy with the Gaussian 09 program package (PBE0/SDD/ 6-31G). ${ }^{64}$ The computational absorption spectra are almost identical to the experimental absorption spectra (Fig. 1 and Fig. S6, ESI $\dagger$ ). The lower energy absorption band of ppy-Pt-3-Cl-Ph $\left(\lambda_{\mathrm{abs}}=445 \mathrm{~nm}\right.$ in THF) is reproduced well by the computation, which predicts one absorption band at $436 \mathrm{~nm}$. The lower energy absorption is due to the highest occupied molecular orbital (HOMO) $\rightarrow$ lowest unoccupied molecular orbital (LUMO) (oscillator strength $\left.f_{\text {osc }}=0.0275,91 \%\right)$ transition. The energy level and frontier molecular orbitals of ppy-Pt-3-Cl-Ph (Fig. 2) reveal that its HOMO is composed primarily of $\pi$-conjugated units of the bridging ligand (iminomethylphenol units), auxiliary ppy ligands (phenyl units), and $\mathrm{Pt}(\mathrm{II})$ ions, which might be due to their electron-donating nature.

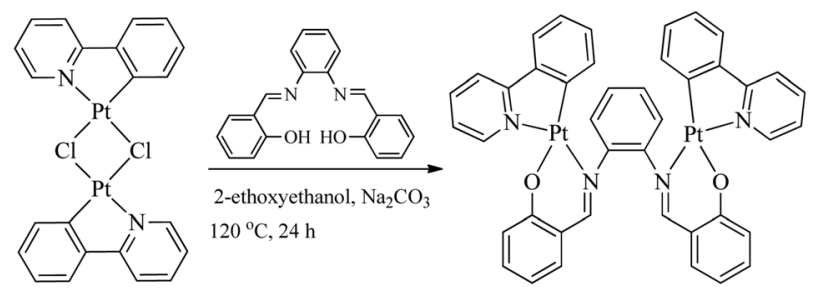

Scheme 2 Synthesis of binuclear $\left[\left(C^{\wedge} N\right) \operatorname{Pt}\left(\mu-\right.\right.$ Salen) $\left.\operatorname{Pt}^{(}\left({ }^{\wedge} N\right)\right]$ complexes. 
Table 1 Photophysical data of the Pt(॥) complexes at room temperature. A sample without emission data means that it is non-emissive

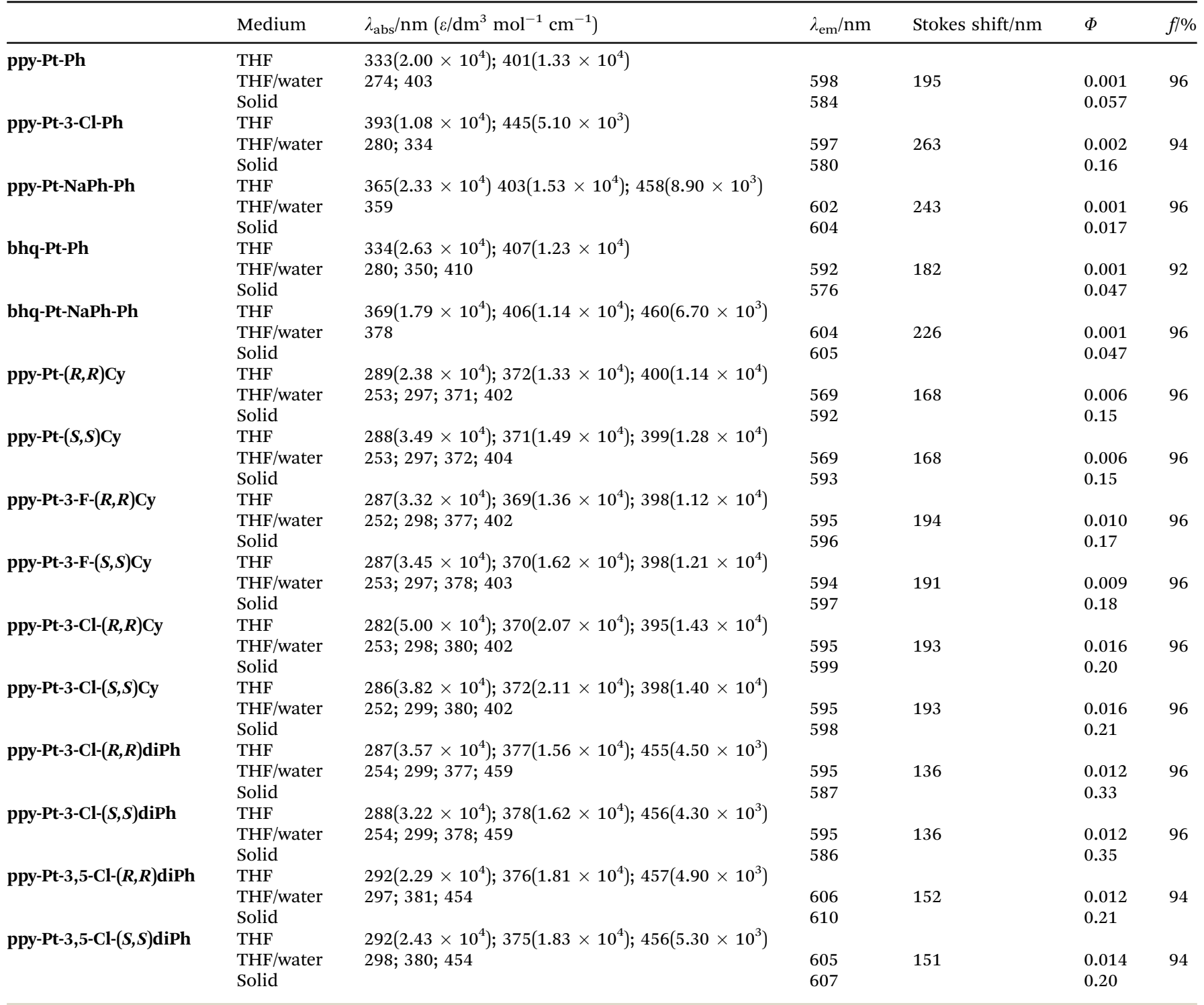

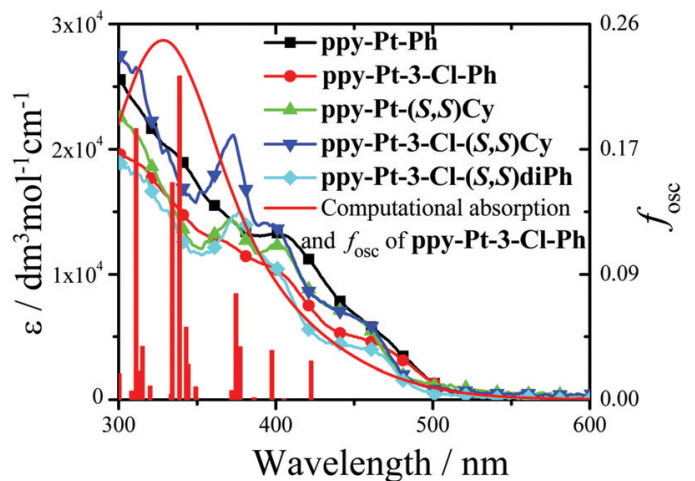

Fig. 1 Computational and experimental (in THF) absorption spectra of some Pt(॥) complexes.

On the contrary, its LUMO is mainly made up of the whole $\pi$-functions of the bridging ligand. Therefore, the lower energy

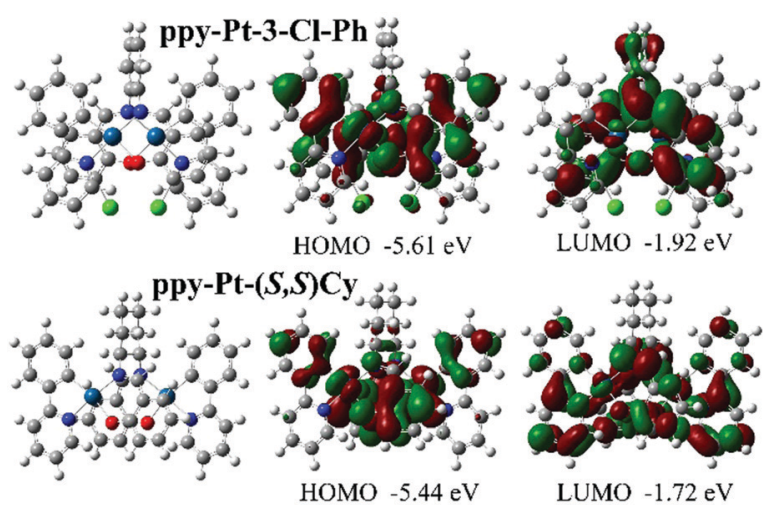

Fig. 2 Computational energy level diagram and frontier molecular orbitals of ppy-Pt-3-Cl-Ph and ppy-Pt-(S,S)Cy (in THF).

absorption can mainly be assigned to singlet intraligand charge transfer $\left({ }^{1} \mathrm{ILCT}\right)$ in the bridging ligand, ligand-to-ligand charge 

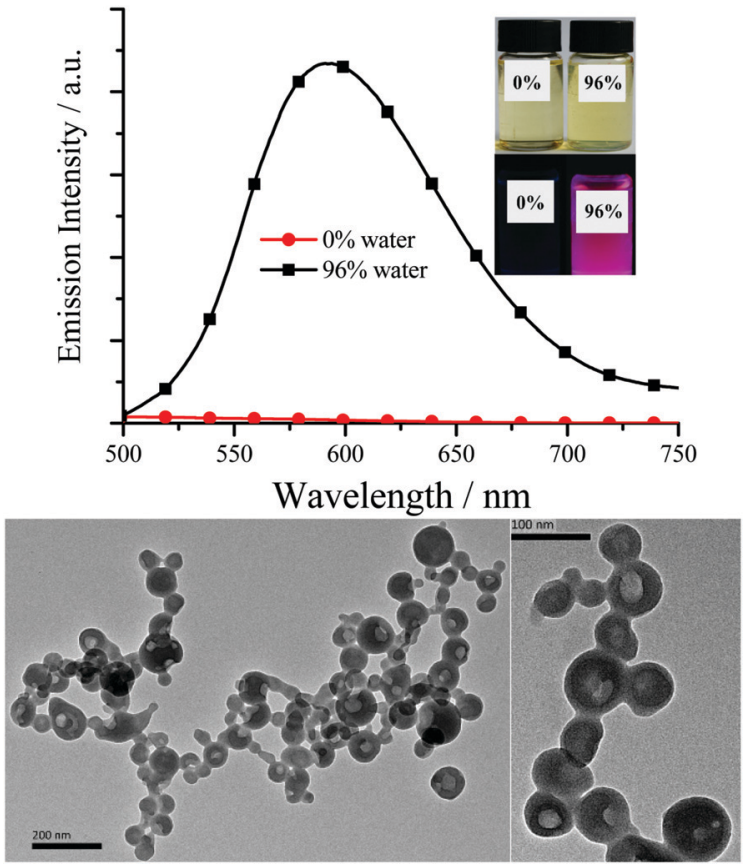

Fig. 3 Top: Emission spectra of ppy-Pt-3-Cl-(S,S)Cy in THF and THF/ water $\left(2.0 \times 10^{-5} \mathrm{~mol} \mathrm{dm}^{-3}\right)$. Inset: Their photographs under room light and $360 \mathrm{~nm}$ UV light. Bottom: Transmission electron microscopy of ppyPt-3-Cl-(S,S)Cy (THF/water, 96\% water) on carbon-coated copper grids after solvent evaporation.

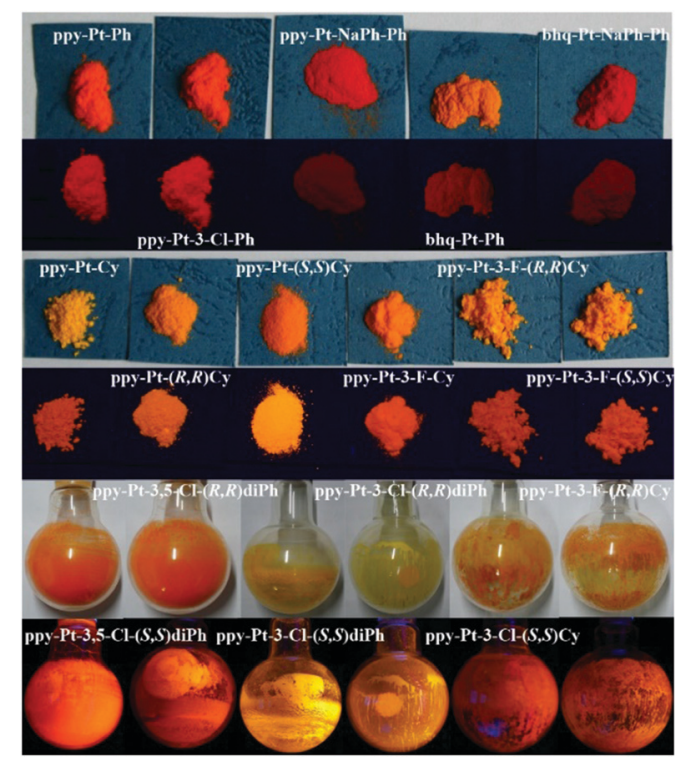

Fig. 4 Photographs of the Pt(॥) complexes under room light and $360 \mathrm{~nm}$ UV light.

transfer $\left({ }^{1}\right.$ LLCT) from auxiliary ligands to the bridging ligand, and metal-to-ligand charge transfer $\left({ }^{1} \mathrm{MLCT}\right)$. The $\mathrm{Cl}$ atoms in the bridging ligand and pyridine rings in auxiliary ligands have little contribution to the lower energy absorption. Un-conjugated bridging ppy-Pt- $(\boldsymbol{S}, \boldsymbol{S}) \mathbf{C y}$ shows a similar transition $(423 \mathrm{~nm}$, $f_{\text {OSC }}=0.0533$, HOMO $\rightarrow$ LUMO, 88\%) (Fig. 2 and Fig. S6, ESI $\dagger$ ) to $\mathbf{p p y - P t - 3 - C l - P h , ~ e x c e p t ~ t h a t ~ t h e ~ p y r i d i n e ~ r i n g s ~ a n d ~ u n - c o n j u g a t e d ~}$

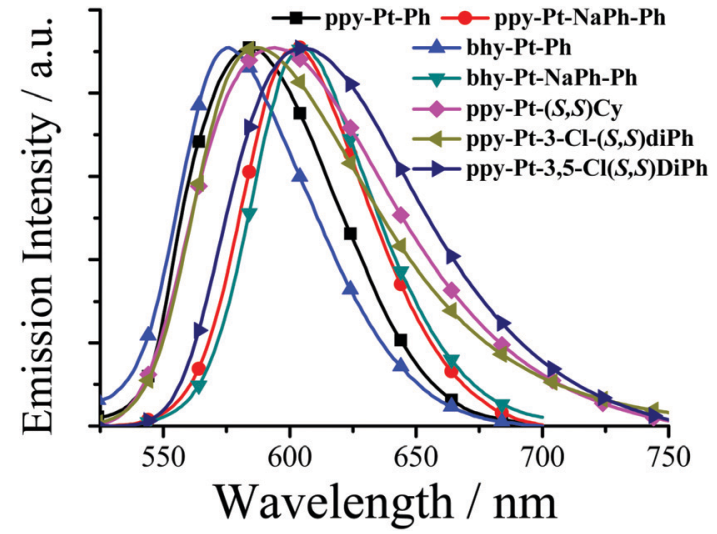

Fig. 5 Normalized emission spectra of some Pt(॥) complexes in the solid state.

bridging cyclohexane have and doesn't have a contribution to the lower energy absorption, respectively.

As expected, all the $\mathrm{Pt}(\mathrm{II})$ complexes are non-emissive (Table 1) in pure dilute $\mathrm{CH}_{2} \mathrm{Cl}_{2}, \mathrm{MeCN}$, benzene, DMSO or THF, as the intramolecular rotations (IVs) of the bridging Salen ligand provide a possible way to non-radiatively annihilate their excited states (Scheme 1c). Nonetheless, their aggregates either in THF/ water or the solid state (Fig. 3-5 and Fig. S7-S11, ESI $\dagger$ ) exhibit strong yellow-red emission $\left(\lambda_{\mathrm{em}}=576-610 \mathrm{~nm} ; \Phi\right.$ up to 0.35$)$ with relative long decay lifetimes $(1.68,2.34,1.72$, and $4.02 \mu \mathrm{s}$ for ppy-Pt-(R,R)Cy, ppy-Pt-(S,S)Cy, ppy-Pt-3-Cl-(R,R)diPh, and ppy-Pt-3-Cl-(S,S)diPh, respectively, Fig. S12, ESI $\dagger$ ), revealing their AIP nature (water is an insoluble solvent). The absorption spectrum of ppy-Pt-3-Cl-(S,S)Cy in THF/water is similar to that in the organic solution of THF (Fig. S2, ESI $\dagger$ ), except that there is an obvious tail in the visible region, indicating the formation of aggregated hollow nanoparticles (Fig. 3). Moreover, their absorption and excitation spectra are similar (Fig. S2, ESI $\dagger$ ), suggesting they have a common excitation pathway, which would not be the case for a different (e.g., dimer) species.

\section{Single crystal structures}

The molecular structures and arrangements play a key role in AIE. ${ }^{65-68}$ Non-covalent interactions are also frequently involved to assist the molecules to orient and assemble. In order to enhance AIE, molecules should stack closely with not only strong non-covalent intermolecular interactions but also weak intermolecular face-to-face $\pi-\pi^{*}$ interactions. The former can ensure elimination of IVs; and the latter would prevent the formation of excimers. We tried many different ways to grow single crystals of these Pt(II) complexes. After dozens of attempts, we obtained suitable single crystals of ppy-Pt-3-Cl-Ph (CCDC: 1589703), ppy-PtNaPh-Ph (CCDC: 1589704), racemic ppy-Pt-Cy (CCDC: 1589683), ppy-Pt-(S,S)Cy (CCDC: 1589684), and ppy-Pt-(R,R)Cy (CCDC: 1589685) for X-ray structure determination by slow diffusion/ evaporation of a $\mathrm{CH}_{2} \mathrm{Cl}_{2} /$ hexane or $\mathrm{CHCl}_{3} /$ hexane solution. $\dagger$ The $\mathrm{X}$-ray single crystals of racemic ppy-Pt-Cy were obtained from a mixture of enantiopure complexes $(1: 1)$ in solution. In general, strong intermolecular interactions in the crystal are in the range 


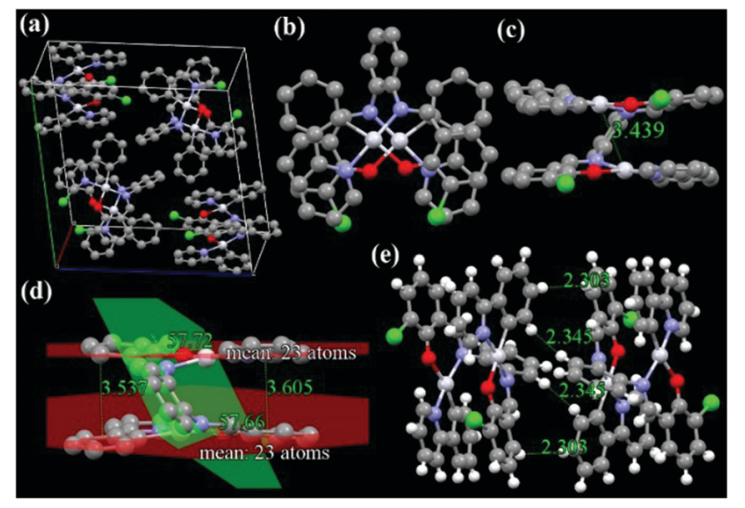

Fig. $6 \mathrm{X}$-ray single crystal structures and packing of ppy-Pt-3-Cl-Ph molecules (a: molecule packing in one crystal cell; b: top view; c and d: side view; e: intermolecular interactions of the two closest molecules). $\mathrm{H}$ atoms are omitted in $\mathrm{a}-\mathrm{d}$.

1.9-2.3 $\AA$ and 2.2-3.0 ̊ for hydrogen bonds and non-hydrogen bonds, respectively. ${ }^{18,36,38,58,63,69}$

The X-ray single-crystal structures and arrangements of ppy-Pt-3-Cl-Ph are shown in Fig. 6 and Fig. S13 (ESI $\dagger$ ). ppy-Pt3-Cl-Ph molecules are stacked to exhibit lamellar packing with a distance of $7.092 \AA$ A. Unlike the square-planar mononuclear $\mathrm{Pt}($ Salen) complexes (Scheme 1a), the I-type binuclear ppy-Pt3-Cl-Ph complex bears two planes of Pt(II) coordination systems that are linked by a central bridge of a benzene ring. The four coordination atoms of $\mathrm{C}^{\wedge} \mathrm{N}^{\wedge} \mathrm{O}^{\wedge} \mathrm{N}$ and central $\mathrm{Pt}^{\mathrm{II}}$ are almost located in one plane and the $\mathrm{Pt}-\mathrm{N}, \mathrm{Pt}-\mathrm{O}$, and $\mathrm{Pt}-\mathrm{C}$ bonds are of similar lengths (2.006-2.068 $\mathrm{\AA}$ ) to what was found in normal Pt(Salen) complexes, ${ }^{54}$ which indicates that the ppy-Pt-3-Cl-Ph complex has a suitable square-planar coordination environment for chelating the $\mathrm{Pt}^{\mathrm{II}}$ cation. Since the dihedral angle between these two Pt(II) coordination systems and the central benzene bridge is $57.72^{\circ}$ and $57.66^{\circ}$, respectively, the two $\operatorname{Pt}$ (II) coordination systems are almost parallel with an interplanar distance $(d)$ of 3.537-3.605 $\mathrm{A}$, which reveals that there are some weak intramolecular $\pi-\pi$ stacking interactions in the ppy-Pt-3Cl-Ph complex. Some modest intramolecular $\mathrm{Pt}^{\mathrm{II}}-\mathrm{Pt}^{\mathrm{II}}$ interactions (3.439 $\AA$ ) are observed as well. Due to its staggered arrangement, there are no strong intermolecular $\pi-\pi$ stacking interactions and $\mathrm{Pt}^{\mathrm{II}}-\mathrm{Pt}^{\mathrm{II}}$ interactions (7.390 $⿱$ A) between two neighboring ppy-Pt-3-Cl-Ph molecules, which would be beneficial in preventing the formation of excimers. On the other hand, many strong intermolecular noncovalent interactions including not only normal $\mathrm{H}-\mathrm{H}(2.303-2.851 \AA), \mathrm{C}-\mathrm{H}(2.793-2.797 \AA)$, and $\mathrm{O}-\mathrm{H}$

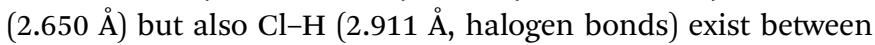
the two neighboring ppy-Pt-3-Cl-Ph molecules. These strong intermolecular interactions could restrict the IVs of the bridging ligand, and thus the phosphorescence is enhanced finally.

With $\pi$-extended conjugation in the bridging ligand, ppy-PtNaPh-Ph molecules (Fig. 7 and Fig. S14, ESI $\dagger$ ) exhibit a similar lamellar packing to ppy-Pt-3-Cl-Ph molecules. The dihedral angle between the two $\mathrm{Pt}$ (II) coordination systems and the central benzene bridge is $51.38^{\circ}$ and $50.55^{\circ}$, respectively. Their interplanar distances are in the range of 3.376-3.456 $\AA$, indicating that

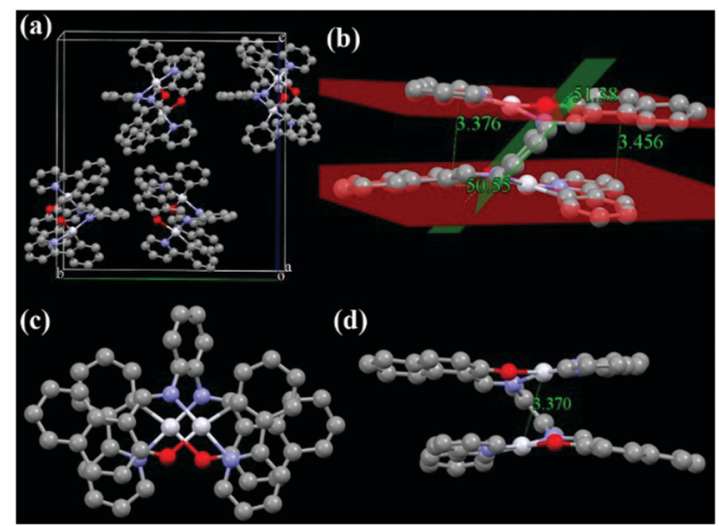

Fig. 7 X-ray single crystal structures and packing of ppy-Pt-NaPh-Ph molecules (a: molecule packing in one crystal cell; $b$ and $d$ : side view; c: top view). $\mathrm{H}$ atoms and $\mathrm{CHCl}_{3}$ solvent molecules are omitted.

intramolecular $\pi-\pi$ stacking interactions in $\mathbf{p p y - P t - N a P h - P h}$ are stronger than those in ppy-Pt-3-Cl-Ph. Moreover, stronger intramolecular $\mathrm{Pt}^{\mathrm{II}}-\mathrm{Pt}^{\mathrm{II}}$ interactions $(3.370 \AA)$ and weaker intermolecular $\mathrm{H}-\mathrm{H}(2.430-2.945 \AA)$ and $\mathrm{C}-\mathrm{H}(2.842 \AA)$ interactions are observed for ppy-Pt-NaPh-Ph molecules. All the above factors lead to solid-state ppy-Pt-NaPh-Ph $\left(\lambda_{\mathrm{em}}=605 \mathrm{~nm} ; \Phi=0.017\right)$ emitting red-shifted emission along with a much lower $\Phi$ than solid-state ppy-Pt-3-Cl-Ph $\left(\lambda_{\mathrm{em}}=580 \mathrm{~nm} ; \Phi=0.16\right)$.

Linked with an un-conjugated Cy ligand, ppy-Pt-(S,S)Cy and ppy-Pt- $(\boldsymbol{R}, \boldsymbol{R})$ Cy molecules (Fig. 8 and Fig. S15, ESI $\dagger$ ) exhibit lamellar packing as well. The molecular structures and arrangements of the ppy-Pt- $(\boldsymbol{S}, \boldsymbol{S}) \mathbf{C y}$ and ppy-Pt- $(\boldsymbol{R}, \boldsymbol{R}) \mathbf{C y}$ enantiomers are similar and mirrored, which might contribute to their similar

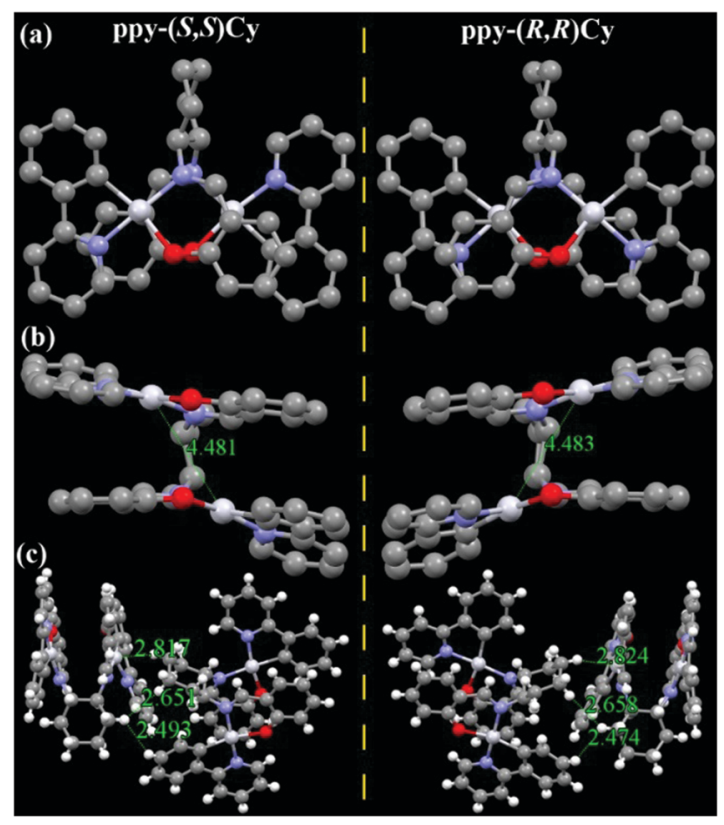

Fig. 8 X-ray single crystal structures and packing of ppy-Pt-(S,S)Cy and ppy-Pt- $(\boldsymbol{R}, \boldsymbol{R})$ Cy molecules (a: top view; b: side view; c: intermolecular interactions of the two neighboring molecules). Some $\mathrm{H}$ atoms and $\mathrm{CH}_{2} \mathrm{Cl}_{2}$ solvent molecules are omitted. 
absorption and AIP properties..$^{38,63,69}$ In this section, ppy-Pt$(\boldsymbol{S}, \boldsymbol{S}) \mathrm{Cy}$ was discussed as an example. Since the un-conjugated Cy bridging ligand is flexible, the two $\mathrm{Pt}$ (II) coordination systems are not parallel with a dihedral angle of $14.12^{\circ}$. There are no intramolecular $\pi-\pi$ stacking interactions and $\mathrm{Pt}^{\mathrm{II}}-\mathrm{Pt}^{\mathrm{II}}$ interactions (4.481 $\AA$ ) in one ppy-Pt- $(\boldsymbol{S}, \boldsymbol{S}) \mathbf{C y}$ molecule. For two neighboring ppy-Pt-(S,S)Cy molecules, however, not only some strong intermolecular $\mathrm{H}-\mathrm{H}(2.353-2.692 \AA)$ and $\mathrm{C}-\mathrm{H}(2.875 \AA)$ interactions but also strong Pt-H (2.817 $\AA)$ interactions are observed. Therefore, solid-state ppy-Pt- $(S, S) \mathbf{C y}\left(\lambda_{\mathrm{em}}=593 \mathrm{~nm}\right.$; $\Phi=0.15)$ has a high $\Phi$.

Racemic ppy-Pt-Cy (Fig. 9 and Fig. S16, ESI $\dagger$ ) has a totally different molecular arrangement from enantiopure ppy-Pt-(S,S)Cy and ppy-Pt- $(\boldsymbol{R}, \boldsymbol{R}) \mathbf{C y}$, even though they have similar AIP properties. In the single crystals of ppy-Pt-Cy, one pair of $(S, S)$ and $(R, R)$ enantiomers $(1: 1)$ was found, and thus these $(R) /(S)$-chiralityinduced interactions ${ }^{38,63}$ between the two enantiomers would help ppy-Pt-Cy molecules arrange in herringbone packing. Similar strong intermolecular $\mathrm{H}-\mathrm{H}(2.390-2.876 \AA)$, C-H (2.825 ̊), and Pt-H (2.881 $\AA$ ) interactions are observed in two neighboring ppy-Pt-Cy molecules. We failed to grow single crystals of the complexes bearing diPh bridging ligands. Our previous work ${ }^{38}$ reveals that diPh ligands have a 1,2-diphenylethane bridge but not a circular bridge of cyclohexane; hence, diPh ligands are more flexible than Cy ligands. We speculate that, compared with Cy-linked complexes, diph-linked complexes would be more flexible as well and consequently pack more closely to enhance AIP. The $\Phi$ of solid-state ppy-Pt-3-Cl-(S,S)diPh is up to 0.35 , which is unexpected for binuclear Pt(II) complexes ${ }^{70}$ and even higher than that of mononuclear Pt(Salen) complexes ( $\Phi$ up to 0.27 in dilute $\mathrm{MeCN}) .{ }^{54}$ The presence of $\mathrm{Cl}$ and $\mathrm{F}$ atoms would aid in AIP through intermolecular halogen bonds (Fig. S13, ESI $\dagger$ ). ${ }^{36-38}$

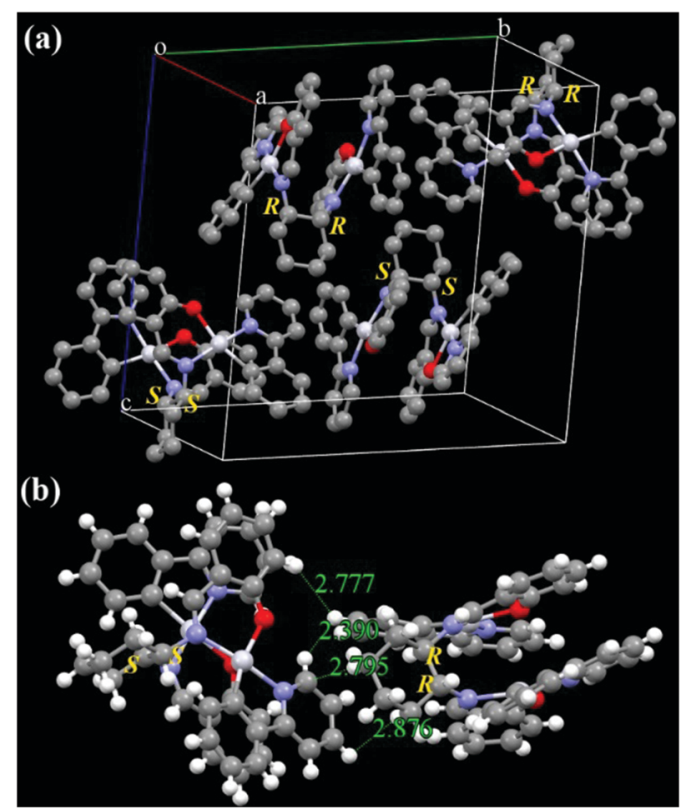

Fig. 9 X-ray single crystal structures and packing of racemic ppy-Pt-Cy molecules (a: molecule packing in one crystal cell; b: intermolecular interactions of the two neighboring molecules). Some $\mathrm{H}$ atoms are omitted.
It is interesting that similar cyclometallated [(ppy)Pt(pop)] (pop = 2-(5-phenyl-1,3,4-oxadiazol-2-yl)phenol) Pt(II) complexes $^{71}$ are known to be emissive in solution. However, some similar cyclometallated $\left[\left(\mathrm{C}^{\wedge} \mathrm{N}\right) \mathrm{Pt}\left(\mathrm{N}^{\wedge} \mathrm{O}\right)\right]$ complexes $^{57}$ and $\left[\left(\mathrm{C}^{\wedge} \mathrm{N}\right) \mathrm{Pt}(\mu-\mathrm{SA})-\right.$ $\left.\mathrm{Pt}\left(\mathrm{C}^{\wedge} \mathrm{N}\right)\right]$ complexes ${ }^{58}$ show strong AIP as well. This might be caused by the differences of their chemical and electronic structures.

\section{Chirality properties}

The un-conjugated Pt(II) complexes with Cy and diPh bridging ligands have two $(S, S)$ or $(R, R)$ chiral carbons and might be used in some special applications of enantioselective catalysis, ${ }^{42}$ chiral recognition, ${ }^{60,61}$ and CPL, ${ }^{62,63}$ and thus their chirality properties were studied by circular dichroism (CD) spectra and TD-DFT calculations (Fig. 10). As example, racemic ppy-Pt-Cy has no CD signals in dilute MeCN. Enantiopure ppy-Pt- $(\boldsymbol{S}, \boldsymbol{S}) \mathbf{C y}$ exhibits three positive Cotton peaks at 390, 353, and $255 \mathrm{~nm}$ and two negative Cotton peaks at 448 and $300 \mathrm{~nm}$. On the other hand, enantiopure ppy-Pt- $(\boldsymbol{R}, \boldsymbol{R}) \mathbf{C y}$ shows exactly the mirror CD spectrum with two positive Cotton peaks at 488 and $300 \mathrm{~nm}$ and three negative Cotton peaks at 391, 352, and $255 \mathrm{~nm}$, indicating the fact that ppy-Pt- $(S, S) C y$ and ppy-Pt- $(R, R) C y$ are a pair of enantiomers. The calculated CD spectrum of ppy-Pt$(\boldsymbol{S}, \boldsymbol{S}) \mathbf{C y}$ fits well with the experimental CD spectrum (Fig. 10), which further confirms its $(S, S)$ chirality. ppy-Pt-3-F-(S,S)Cy, ppyPt-3-F $(R, R) C y$, ppy-Pt-3-Cl- $(S, S)$ diPh, and ppy-Pt-3-Cl-(R,R)diPh have similar chirality properties to ppy-Pt- $(S, S) C y$ and ppy-Pt$(\boldsymbol{R}, \boldsymbol{R}) \mathbf{C y}$, which is consistent with their similar conjugation and chiral carbons. Our previous work ${ }^{38}$ demonstrated that the free bridging $\mathrm{Cy}$ and diPh ligands have identical CD signals to the corresponding complexes at high energy $(<370 \mathrm{~nm})$, and thus the high-energy CD signals can be assigned to the chiral bridging Salen ligands themselves $\left({ }^{1}\right.$ ILCT) and the lower-energy CD signals $(>370 \mathrm{~nm})$ can be mainly assigned to ${ }^{1}$ LLCT and ${ }^{1}$ MLCT.

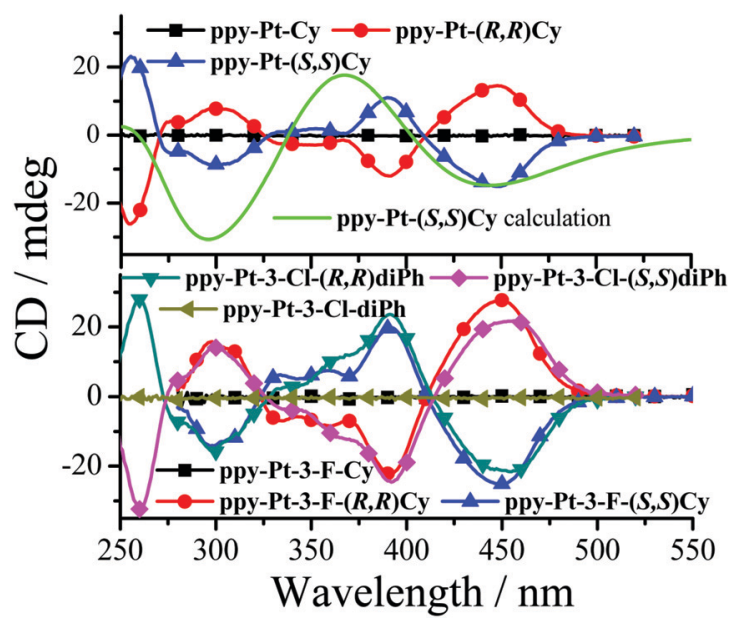

Fig. 10 Experimental CD spectra of ppy-Pt-(S,S)Cy, ppy-Pt- $(R, R) C y$, racemic ppy-Pt-cy, ppy-Pt-3-F-(S,S)Cy, ppy-Pt-3-F(R,R)Cy, racemic ppyPt-3-F-Cy, ppy-Pt-3-Cl-(S,S)diPh, ppy-Pt-3-Cl- $(R, R)$ diPh, and racemic ppy-Pt-3-Cl-diPh $\left(5.0 \times 10^{-5} \mathrm{~mol} \mathrm{dm}^{-3}\right.$ in MeCN). Computational CD spectra of ppy-Pt-(S,S)Cy (in THF). 


\section{Luminescence mechanism}

DFT was used to calculate optimized singlet- and triplet-state structures of gas-state ppy-Pt- $(\boldsymbol{S}, \boldsymbol{S}) \mathbf{C y}$. As shown in Fig. 11, in the gas state or dilute solution, the optimized singlet- and tripletstate structures of ppy-Pt- $(\boldsymbol{S}, \boldsymbol{S}) \mathbf{C y}$ are different from its singlecrystal structure, which would indicate that the $\mathrm{C}-\mathrm{N}$ single bonds of the bridging Salen ligand (Scheme 1c) may be rotatable and provide a possible way to non-radiatively annihilate the excited states consequently. ${ }^{63}$ The time-resolved emission spectra (Fig. S12, ESI $\dagger$ ) reveal that the Pt(II) complexes only have one type of emission decay lifetime in the region of 1.68-4.02 $\mu$ s. This indicates that the emission may be either phosphorescence or delayed fluorescence. For metal-organic complexes, delayed fluorescence is often observed for $\mathrm{Cu}(\mathrm{I}), \mathrm{Ag}(\mathrm{I}) \mathrm{Au}(\mathrm{I})$, and $\mathrm{Sn}$ (Iv) complexes. $^{72,73}$ For $\mathrm{Pt}(\mathrm{II})$ complexes, the emission is often phosphorescence rather than delayed fluorescence. ${ }^{1-8}$ Moreover, we used DFT to calculate the singlet-triplet energy gap $\Delta E_{\mathrm{ST}}$, defined as the gap between the lowest energy triplet state $\left(\mathrm{T}_{1}\right)$ and the lowest energy singlet state $\left(\mathrm{S}_{1}\right)$. When $\Delta E_{\mathrm{ST}}$ is sufficiently small, taken usually as $<0.1 \mathrm{eV}$, the upconversion from the triplet state to the singlet state by reverse intersystem-crossing becomes possible. ${ }^{74}$ The $\Delta E_{\mathrm{ST}}$ of ppy-Pt-(S,S)Cy is $0.27 \mathrm{eV}$, which is much bigger than $0.1 \mathrm{eV}$. Therefore, the emission of $\mathrm{Pt}(\mathrm{II})$ complexes is phosphorescence rather than delayed fluorescence.

It is surprising that the quantum yield (around 0.01) of $\mathrm{Pt}$ (II) complexes in the THF/water mixture is quite low. The solid powders of ppy-Pt- $(\boldsymbol{S}, \boldsymbol{S}) \mathbf{C y}$ have intense and sharp X-ray powder diffraction peaks (Fig. S17, ESI $\dagger$ ), which indicate that the solid powders are mainly microcrystalline and the emission might be caused by the aggregated crystallites. However, the cast film of ppy-Pt-3-F-(S,S)Cy-doped poly(methyl methacrylate) (PMMA) emits strong emission as well, revealing that the amorphous and aggregated Pt(II) complex in PMMA is emissive (Fig. S18, $\mathrm{ESI} \dagger)$. Therefore, the low quantum yield in the THF/water mixture might be caused by self-assembly (Fig. 3). Of course, we can't exclude the possibility of crystallization-induced emission.

\section{Experimental}

\section{Materials and instrumentation}

All reagents were purchased from commercial suppliers and used without further purification. All commercial chemicals
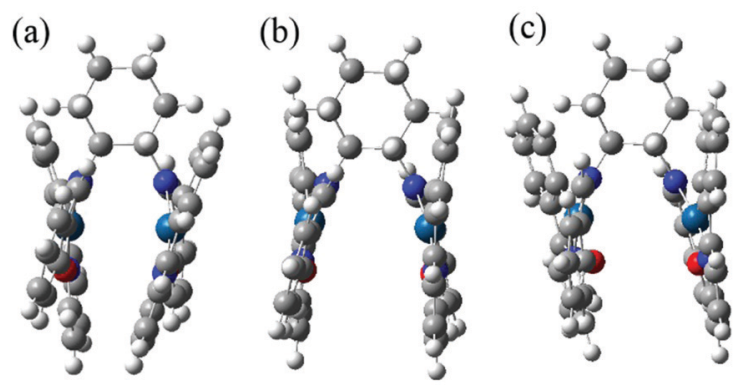

Fig. 11 Single-crystal structure (a) and optimized singlet- (b) and tripletstate (c) structures of gas-state ppy-Pt-(S,S)Cy. were used without further purification unless otherwise stated. UV/visible absorption spectra were recorded using a UV 765 spectrophotometer with quartz cuvettes of $1 \mathrm{~cm}$ pathlength. Fluorescence spectra were obtained using an F-7000 fluorescence spectrophotometer (Hitachi) at room temperature. The slit width was $5.0 \mathrm{~nm}$ for both excitation and emission. The photon multiplier voltage was $700 \mathrm{~V}$. Fluorescence lifetime data were determined in a $1 \mathrm{~mm}$ cell on a Hamamatsu FL920S instrument. The single-crystals were obtained by slow diffusion/ evaporation of a $\mathrm{CH}_{2} \mathrm{Cl}_{2} / \mathrm{CHCl}_{3} /$ hexane solution at room temperature during about one week.

${ }^{1} \mathrm{H}$ and ${ }^{13} \mathrm{C}$ NMR spectra were recorded on a Brüker Advance 400 spectrometer $\left({ }^{1} \mathrm{H}: 400 \mathrm{MHz},{ }^{13} \mathrm{C}\right.$ : $\left.101 \mathrm{MHz}\right)$. Chemical shifts $(\delta)$ for ${ }^{1} \mathrm{H}$ and ${ }^{13} \mathrm{C}$ NMR spectra are given in ppm relative to TMS. The residual solvent signals were used as references for ${ }^{1} \mathrm{H}$ and ${ }^{13} \mathrm{C}$ NMR spectra and the chemical shifts converted to the TMS scale $\left(\mathrm{CDCl}_{3}: \delta_{\mathrm{H}}=7.26 \mathrm{ppm}, \delta_{\mathrm{C}}=77.16 \mathrm{ppm}\right)$. HR-MS were obtained with a Waters-Q-TOF-Premier (electrospray ionization mass spectrometry, ESI). X-Ray single-crystal diffraction data were collected on an Oxford Xcalibur E CCD area-detector diffractometer.

\section{Measurement of fluorescence quantum yield $(\Phi)$}

The quantum yield of a solution sample was measured by the optically dilute method of Demas and Crosby with a standard of quinine sulfate $\left(\Phi_{\mathrm{r}}=0.55\right.$, quinine in $0.05 \mathrm{~mol} \mathrm{dm}^{-3}$ sulfuric acid) calculated by: $\Phi_{\mathrm{s}}=\Phi_{\mathrm{r}}\left(B_{\mathrm{r}} / B_{\mathrm{S}}\right)\left(n_{\mathrm{s}} / n_{\mathrm{r}}\right)^{2}\left(D_{\mathrm{s}} / D_{\mathrm{r}}\right)$, where the subscripts $\mathrm{s}$ and $\mathrm{r}$ refer to the sample and reference standard solution respectively; $n$ is the refractive index of the solvents; and $D$ is the integrated intensity. The excitation intensity $B$ is calculated by: $B=1-10^{-A L}$, where $A$ is the absorbance at the excitation wavelength and $L$ is the optical path length $(L=1 \mathrm{~cm}$ in all cases). The refractive indices of the solvents at room temperature are taken from standard sources. Errors for the $\Phi$ values $( \pm 10 \%)$ are estimated. The quantum yield of a solid sample was measured by an integrating sphere.

\section{Computational details}

The program Gaussian 09 was employed to perform DFT and TD-DFT calculations based on the X-ray single-crystal structure of the Pt(II) complexes. The ground state geometry was optimized using DFT and excited states were predicted using the ground state geometry using TD-DFT, from which UV/vis absorption and CD spectra were predicted. Calculations were run at the PBE0/SDD/ 6-31G level (pcm method; 50 singlet-singlet transitions). ${ }^{64}$

\section{General procedure for the preparation of the $\mathrm{Pt}$ (II) complexes}

Bridging ligands were synthesized according to our previous work. ${ }^{38}$ The Pt(II) complexes were synthesized according to a procedure modified from that reported in the literature. ${ }^{58} \mathrm{Pt}$ (II) dichloro-bridged dimers were synthesized from the starting materials of $\mathrm{K}_{2} \mathrm{PtCl}_{4}$ and 2-phenylpyridine according to a previous report. ${ }^{59}$ A solution of $\mathrm{Pt}(\mathrm{II})$ dichloro-bridged dimers, 0.5 equiv. of the bridging ligand and 5 equiv. of $\mathrm{Na}_{2} \mathrm{CO}_{3}$ in 2-ethoxyethanol was heated to reflux for $24 \mathrm{~h}$ under a $\mathrm{N}_{2}$ atmosphere. Then the reaction mixture was concentrated under reduced pressure. A few milliliters of dichloromethane was added gradually to give the 
crude product, which was purified by silica gel column chromatography using dichloromethane as the eluent to give pure products with moderate yields (10-28\%).

ppy-Pt-Ph. (12\% yield); HPLC $m / z$ 1034.1566 $\left[[\mathrm{M}+\mathrm{Na}]^{+}\right]$ (calcd $m / z$ 1034.1541).

ppy-Pt-3-Cl-Ph. (15\% yield); HPLC $m / z$ 1102.0755 [[M $\left.+\mathrm{Na}]^{+}\right]$ (calcd $m / z$ 1102.0761).

ppy-Pt-NaPh-Ph. (10\% yield); HPLC $m / z$ 11134.1854 [[M + $\left.\mathrm{Na}]^{+}\right]$(calcd $m / z$ 1134.1841).

bhq-Pt-Ph. (11\% yield); HPLC $m / z$ 1082.1566 $\left[[\mathrm{M}+\mathrm{Na}]^{+}\right]$ (calcd $m / z$ 1082.1541).

bhq-Pt-NaPh-Ph. (10\% yield); HPLC $m / z$ 1182.1883 [[M $\left.+\mathrm{Na}]^{+}\right]$ (calcd $m / z$ 1182.1854).

ppy-Pt-(R,R)Cy. (25\% yield); ${ }^{1} \mathrm{H}$ NMR (400 $\left.\mathrm{MHz}, \mathrm{CDCl}_{3}, \delta\right)$ : $9.14(\mathrm{~s}, 2 \mathrm{H}), 8.14(\mathrm{~s}, 2 \mathrm{H}), 7.66(\mathrm{t}, 2 \mathrm{H}), 7.40(\mathrm{~d}, 2 \mathrm{H}), 7.33(\mathrm{~s}, 2 \mathrm{H})$, $7.13(\mathrm{~s}, 2 \mathrm{H}), 7.00(\mathrm{dd}, 8 \mathrm{H}), 6.81(\mathrm{~d}, 2 \mathrm{H}), 6.59(\mathrm{~d}, 2 \mathrm{H}), 6.07(\mathrm{t}, 2 \mathrm{H})$, 4.95 (d, 2H), 2.60 (d, 2H), $1.94(\mathrm{~s}, 4 \mathrm{H}), 1.57$ (s, 2H); ${ }^{13} \mathrm{C}$ NMR $\left(101 \mathrm{MHz}, \mathrm{CDCl}_{3}, \delta\right): 167.13,165.16,160.28,146.51,146.03$, 143.54, 137.54, 134.09, 133.98, 133.51, 129.19, 123.10, 122.87, 122.22, 121.58, 120.36, 117.61, 113.81, 75.22, 33.95, 24.83; HPLC $m / z 1041.2037\left[[\mathrm{M}+\mathrm{Na}]^{+}\right]$(calcd $m / z$ 1041.2031).

ppy-Pt-(S,S)Cy. (27\% yield); ${ }^{1} \mathrm{H}$ NMR (400 MHz, $\mathrm{CDCl}_{3}, \delta$ ): $9.14(\mathrm{~s}, 2 \mathrm{H}), 8.14(\mathrm{~s}, 2 \mathrm{H}), 7.66(\mathrm{t}, 2 \mathrm{H}), 7.40(\mathrm{~d}, 2 \mathrm{H}), 7.33(\mathrm{~s}, 2 \mathrm{H})$, $7.13(\mathrm{~s}, 2 \mathrm{H}), 7.00(\mathrm{dd}, 8 \mathrm{H}), 6.81(\mathrm{~d}, 2 \mathrm{H}), 6.59(\mathrm{~d}, 2 \mathrm{H}), 6.07(\mathrm{t}, 2 \mathrm{H})$, $4.95(\mathrm{~d}, 2 \mathrm{H}), 2.60(\mathrm{~d}, 2 \mathrm{H}), 1.94(\mathrm{~s}, 4 \mathrm{H}), 1.57$ (s, 2H); ${ }^{13} \mathrm{C}$ NMR $\left(101 \mathrm{MHz}, \mathrm{CDCl}_{3}, \delta\right): 167.13,165.16,160.28,146.51,146.03$, 143.54, 137.54, 134.09, 133.98, 133.51, 129.19, 123.10, 122.87, 122.22, 121.58, 120.36, 117.61, 113.81, 75.22, 33.95, 24.83; HPLC $m / z 1041.2037\left[[\mathrm{M}+\mathrm{Na}]^{+}\right]$(calcd $m / z$ 1041.2031).

ppy-Pt-3-F-(R,R)Cy. (28\% yield); ${ }^{1} \mathrm{H}$ NMR (400 $\mathrm{MHz}, \mathrm{CDCl}_{3}$, $\delta): 9.23(\mathrm{dd}, 2 \mathrm{H}), 7.94(\mathrm{~d}, 2 \mathrm{H}), 7.67(\mathrm{td}, 2 \mathrm{H}), 7.36-7.28(\mathrm{~m}, 4 \mathrm{H})$, 7.19-7.09 (m, 4H), 7.08-6.98 (m, 4H), 6.71 (ddd, 2H), 6.54 (d, $J=8.0 \mathrm{~Hz}, 2 \mathrm{H}), 5.97(\mathrm{td}, 2 \mathrm{H}), 4.96(\mathrm{~d}, 2 \mathrm{H}), 2.53(\mathrm{~d}, 2 \mathrm{H}), 2.00(\mathrm{~d}$, $4 \mathrm{H}), 1.60(\mathrm{~s}, 2 \mathrm{H}) ;{ }^{13} \mathrm{C} \mathrm{NMR}\left(101 \mathrm{MHz}, \mathrm{CDCl}_{3}, \delta\right):$ 166.76, 159.61, 159.58, 155.63, 154.29, 154.15, 153.22, 146.73, 146.15, 143.09, 137.51, 133.86, 129.13, 128.39, 128.35, 124.88, 124.83, 122.97, 122.29, 120.73, 117.48, 117.38, 117.30, 111.99, 111.92, 76.07, 32.86, 24.69; HPLC $m / z$ 1077.8883 [[M + Na $\left.]^{+}\right]$(calcd $m / z$ 1077.8875).

ppy-Pt-3-F-(S,S)Cy. (26\% yield); ${ }^{1} \mathrm{H}$ NMR (400 $\mathrm{MHz}, \mathrm{CDCl}_{3}$, $\delta): 9.23(\mathrm{dd}, 2 \mathrm{H}), 7.94(\mathrm{~d}, 2 \mathrm{H}), 7.67(\mathrm{td}, 2 \mathrm{H}), 7.36-7.28(\mathrm{~m}, 4 \mathrm{H})$, 7.19-7.09 (m, 4H), 7.08-6.98 (m, 4H), 6.71 (ddd, 2H), 6.54 (d, $2 \mathrm{H}), 5.97(\mathrm{td}, 2 \mathrm{H}), 4.96(\mathrm{~d}, 2 \mathrm{H}), 2.53(\mathrm{~d}, 2 \mathrm{H}), 2.00(\mathrm{~d}, 4 \mathrm{H}), 1.60(\mathrm{~s}$, $2 \mathrm{H}) ;{ }^{13} \mathrm{C}$ NMR (101 MHz, $\mathrm{CDCl}_{3}, \delta$ ): 166.76, 159.61, 159.58, 155.63 , 154.29, 154.15, 153.22, 146.73, 146.15, 143.09, 137.51, 133.86, 129.13, 128.39, 128.35, 124.88, 124.83, 122.97, 122.29, $120.73,117.48,117.38,117.30,111.99,111.92,76.07,32.86$, 24.69; HPLC $m / z 1077.8883\left[[\mathrm{M}+\mathrm{Na}]^{+}\right]$(calcd $m / z$ 1077.8875).

ppy-Pt-3-Cl-(R,R)Cy. (24\% yield); ${ }^{1} \mathrm{H}$ NMR (400 MHz, $\left.\mathrm{CDCl}_{3}, \delta\right)$ : $9.35(\mathrm{~s}, 2 \mathrm{H}), 7.95(\mathrm{~s}, 2 \mathrm{H}), 7.67(\mathrm{td}, 2 \mathrm{H}), 7.33(\mathrm{dd}, 4 \mathrm{H}), 7.23-6.88$ $(\mathrm{m}, 10 \mathrm{H}), 6.68(\mathrm{dd}, 2 \mathrm{H}), 5.98(\mathrm{t}, 2 \mathrm{H}), 4.95(\mathrm{~d}, 2 \mathrm{H}), 2.53(\mathrm{~d}, 2 \mathrm{H}), 2.02(\mathrm{~d}$, $4 \mathrm{H}), 1.61(\mathrm{t}, 2 \mathrm{H}) ;{ }^{13} \mathrm{C} \mathrm{NMR}\left(101 \mathrm{MHz}, \mathrm{CDCl}_{3}, \delta\right):$ 166.50, 160.24, 159.26, 147.28, 146.33, 143.18, 137.43, 133.88, 132.89, 132.18, 129.09, 125.57, 123.68, 122.98, 122.22, 120.83, 117.27, 113.39, 76.18, 33.05, 24.46; HPLC $m / z$ 1109.1252 [[M + Na $\left.]^{+}\right]$(calcd $m / z$ 1109.1249).

ppy-Pt-3-Cl-(S,S)Cy. (22\% yield); ${ }^{1} \mathrm{H}$ NMR (400 MHz, $\mathrm{CDCl}_{3}, \delta$ ): 9.35 (s, 2H), 7.95 (s, 2H), 7.67 (td, 2H), 7.33 (dd, 4H), 7.23-6.88 (m, 10H), $6.68(\mathrm{dd}, 2 \mathrm{H}), 5.98(\mathrm{t}, 2 \mathrm{H}), 4.95(\mathrm{~d}, 2 \mathrm{H}), 2.53(\mathrm{~d}, 2 \mathrm{H}), 2.02(\mathrm{~d}$, $4 \mathrm{H}), 1.61(\mathrm{t}, 2 \mathrm{H}) ;{ }^{13} \mathrm{C}$ NMR (101 MHz, $\left.\mathrm{CDCl}_{3}, \delta\right):$ 166.50, 160.24, 159.26, 147.28, 146.33, 143.18, 137.43, 133.88, 132.89, 132.18, 129.09, 125.57, 123.68, 122.98, 122.22, 120.83, 117.27, 113.39, 76.18, 33.05, 24.46; HPLC $m / z$ 1109.1252 [[M + Na $\left.]^{+}\right]$(calcd $m / z$ 1109.1249).

ppy-Pt-3-Cl-(R,R)diPh. (13\% yield); ${ }^{1} \mathrm{H}$ NMR $(400 \mathrm{MHz}$, $\left.\mathrm{CDCl}_{3}, \delta\right): 9.45(\mathrm{~d}, 2 \mathrm{H}), 7.78-7.66(\mathrm{~m}, 4 \mathrm{H}), 7.56-7.45(\mathrm{~m}, 6 \mathrm{H})$, 7.37-7.27 (m, 8H), 7.23-7.19 (m, 2H), 7.13 (ddd, 8H), 7.00 (d, 2H), 6.25 (dd, 2H), 5.95 (t, 2H); ${ }^{13} \mathrm{C} \mathrm{NMR} \mathrm{(101} \mathrm{MHz,} \mathrm{CDCl}_{3}, \delta$ ): 166.43, 165.06, 158.99, 147.11, 146.92, 140.93, 140.41, 137.57, 133.05, 132.80, 132.00, 129.24, 128.84, 128.51, 128.08, 125.37, $123.42,122.59,120.62,117.51,113.27,73.08 ;$ HPLC $\mathrm{m} / z$ $1207.1412\left[[\mathrm{M}+\mathrm{Na}]^{+}\right]$(calcd $m / z$ 1207.1408).

ppy-Pt-3-Cl-(S,S)diPh. (15\% yield); ${ }^{1} \mathrm{H}$ NMR $(400 \mathrm{MHz}$, $\left.\mathrm{CDCl}_{3}, \delta\right): 9.45(\mathrm{~d}, 2 \mathrm{H}), 7.78-7.66(\mathrm{~m}, 4 \mathrm{H}), 7.56-7.45(\mathrm{~m}, 6 \mathrm{H})$, 7.37-7.27 (m, 8H), 7.23-7.19 (m, 2H), 7.13 (ddd, 8H), 7.00 (d, 2H), 6.25 (dd, 2H), 5.95 (t, 2H); ${ }^{13} \mathrm{C}$ NMR (101 MHz, $\mathrm{CDCl}_{3}, \delta$ ): 166.43, 165.06, 158.99, 147.11, 146.92, 140.93, 140.41, 137.57, 133.05, 132.80, 132.00, 129.24, 128.84, 128.51, 128.08, 125.37, $123.42,122.59,120.62,117.51,113.27,73.08 ;$ HPLC $\mathrm{m} / \mathrm{z}$ $1207.1412\left[[\mathrm{M}+\mathrm{Na}]^{+}\right]$(calcd $m / z$ 1207.1408).

ppy-Pt-3,5-Cl-(R,R)diPh. (13\% yield); ${ }^{1} \mathrm{H}$ NMR (400 MHz, $\left.\mathrm{CDCl}_{3}, \delta\right): 9.37(\mathrm{~d}, 2 \mathrm{H}), 7.78-7.70(\mathrm{~m}, 4 \mathrm{H}), 7.40(\mathrm{ddd}, 16 \mathrm{H})$, 7.13 (ddd, 8H), 7.02 (d, 2H), 6.17 (d, 2H); ${ }^{13} \mathrm{C}$ NMR (101 MHz, $\left.\mathrm{CDCl}_{3}, \delta\right): 166.00,164.58,157.50,146.98,146.64,140.15$, $137.89,132.60,131.91,131.01,129.10,129.00,128.85,128.30$, 126.27, 123.53, 123.33, 123.19, 120.60, 117.58, 116.77, 72.91; HPLC $m / z 1275.0639\left[[\mathrm{M}+\mathrm{Na}]^{+}\right]$(calcd $m / z$ 1275.0629).

ppy-Pt-3,5-Cl-(S,S)diPh. (13\% yield); ${ }^{1} \mathrm{H}$ NMR $(400 \mathrm{MHz}$, $\left.\mathrm{CDCl}_{3}, \delta\right): 9.37(\mathrm{~d}, 2 \mathrm{H}), 7.78-7.70(\mathrm{~m}, 4 \mathrm{H}), 7.40$ (ddd, $\left.16 \mathrm{H}\right)$, 7.13 (ddd, 8H), 7.02 (d, 2H), 6.17 (d, 2H); ${ }^{13} \mathrm{C}$ NMR (101 MHz, $\left.\mathrm{CDCl}_{3}, \delta\right): 166.00,164.58,157.50,146.98,146.64,140.15$, $137.89,132.60,131.91,131.01,129.10,129.00,128.85,128.30$, 126.27, 123.53, 123.33, 123.19, 120.60, 117.58, 116.77, 72.91; HPLC $m / z 1275.0639\left[[\mathrm{M}+\mathrm{Na}]^{+}\right]$(calcd $m / z$ 1275.0629).

\section{Conclusions}

In summary, we have developed a straightforward way to prepare a new class of binuclear cyclometalated Pt(II) complexes with wellknown tetradentate Salen ligands as bridging ligands. These double-layer stacked complexes exhibit strong AIP through welltuned intramolecular Pt-Pt interactions and strong multiple intermolecular interactions, such as $\mathrm{H}-\mathrm{H}, \mathrm{C}-\mathrm{H}, \mathrm{O}-\mathrm{H}, \mathrm{Cl}-\mathrm{H}$, and $\mathrm{Pt}-\mathrm{H}$ interactions. Furthermore, chirality can be facile to introduce by the presence of chiral $(S, S)$ and $(R, R)$ cyclohexane and 1,2diphenylethane in the bridging Salen ligands, which might provide a new paradigm in the design of AIP active dyes for developing phosphorescent materials, enantioselective catalysis, chiral recognition, CPL, and so on.

\section{Conflicts of interest}

There are no conflicts to declare. 


\section{Acknowledgements}

This work was supported by the National Natural Science Foundation of China (no. 21871192) and Sichuan Science and Technology Program (no. 2018JY0559). We acknowledge the comprehensive training platform of the specialized laboratory of the College of Chemistry, Sichuan University, for material analysis. We would like to thank the Analytical \& Testing Center of Sichuan University for CCD X-ray single crystal diffractometer work and circular dichroism CD spectrometer work. We are grateful to Daibing Luo and Yani Xie for help with the single crystal and circular dichroism measurements.

\section{Notes and references}

1 C. W. Chan, L. K. Cheng and C. M. Che, Coord. Chem. Rev., 1994, 132, 87-97.

2 F. N. Castellano, I. E. Pomestchenko, E. Shikhova, F. Hua, M. L. Muro and N. Rajapakse, Coord. Chem. Rev., 2006, 250, 1819-1828.

3 J. A. G. Williams, Top. Curr. Chem., 2007, 281, 205-268.

4 J. A. G. Williams, S. Develay, D. L. Rochester and L. Murphy, Coord. Chem. Rev., 2008, 252, 2596-2611.

5 L. Murphy and J. A. G. Williams, Top. Organomet. Chem., 2010, 28, 75-111.

6 Y. Feng, J. H. Cheng, L. Zhou, X. G. Zhou and H. F. Xiang, Analyst, 2012, 137, 4885-4901.

7 H. F. Xiang, J. H. Cheng, X. F. Ma, X. G. Zhou and J. J. Chruma, Chem. Soc. Rev., 2013, 42, 6128-6185.

8 K. Li, G. S. M. Tong, Q. Wan, G. Cheng, W. Y. Tong, W. H. Ang, W. L. Kwong and C. M. Che, Chem. Sci., 2016, 7, 1653-1673.

9 S. Campagna, F. Puntoriero and F. Nastasi, Top. Curr. Chem., 2007, 280, 117-214.

10 Y. Chi and P. T. Chou, Chem. Soc. Rev., 2007, 36, 1421-1431.

11 L. Flamigni, A. Barbieri, C. Sabatini, B. Ventura and F. Barigelletti, Top. Curr. Chem., 2007, 281, 143-203.

12 Y. You and S. Y. Park, Dalton Trans., 2009, 1267-1282.

13 A. Y. Y. Tam and V. W. W. Yam, Chem. Soc. Rev., 2013, 42, 1540-1567.

14 V. W. W. Yam, V. K. M. Au and S. Y. L. Leung, Chem. Rev., 2015, 115, 7589-7728.

15 X. F. Ma, R. Sun, J. H. Cheng, J. Y. Liu, F. Gou, H. F. Xiang and X. G. Zhou, J. Chem. Educ., 2016, 93, 345-350.

16 J. Luo, Z. Xie, J. W. Y. Lam, L. Cheng, H. Chen, C. Qiu, H. S. Kwok, X. Zhan, Y. Liu, D. Zhu and B. Z. Tang, Chem. Commun., 2001, 1740-1741.

17 Y. Hong, J. W. Y. Lam and B. Z. Tang, Chem. Soc. Rev., 2011, 40, 5361-5388.

18 J. Mei, N. L. C. Leung, R. T. K. Kwok, J. W. Y. Lam and B. Z. Tang, Chem. Rev., 2015, 115, 11718-11940.

19 L. Ravotto and P. Ceroni, Coord. Chem. Rev., 2017, 346, 62-76.

20 K. Saito, Y. Hamada, H. Takahashi, T. Koshiyama and M. Kato, Jpn. J. Appl. Phys., Part 2, 2005, 44, L500.
21 B. Ma, J. Li, P. I. Djurovich, M. Yousufuddin, R. Bau and M. E. Thompson, J. Am. Chem. Soc., 2005, 127, 28-29.

22 B. Ma, P. I. Djurovich, S. Garon, B. Alleyne and M. E. Thompson, Adv. Funct. Mater., 2006, 16, 2438-2446.

23 A. A. Rachford and F. N. Castellano, Inorg. Chem., 2009, 48, 10865-10867.

24 S. Jamali, R. Czerwieniec, R. Kia, Z. Jamshidi and M. Zabel, Dalton Trans., 2011, 40, 9123-9130.

25 S. W. Lai, M. C. W. Chan, T. C. Cheung, S. M. Peng and C. M. Che, Inorg. Chem., 1999, 38, 4046-4055.

26 W. Lu, M. C. W. Chan, N. Zhu, C. M. Che, C. Li and Z. Hui, J. Am. Chem. Soc., 2004, 126, 7639-7651.

27 C. K. Koo, B. Lam, S. K. Leung, M. H. W. Lam and W. Y. A. Wong, J. Am. Chem. Soc., 2006, 128, 16434-16435.

28 K. W. Wang, J. L. Chen, Y. M. Cheng, M. W. Chung, C. C. Hsieh, G. H. Lee, P. T. Chou, K. Chen and Y. Chi, Inorg. Chem., 2010, 49, 1372-1383.

29 R. P. L. Tang, K. M. C. Wong, N. Zhu and V. W. W. Yam, Dalton Trans., 2009, 3911-3922.

30 H. Leopold, M. Tenne, A. Tronnier, S. Metz, I. Mgnster, G. Wagenblast and T. Strassner, Angew. Chem., Int. Ed., 2016, 55, 15779-15782.

31 P. Pinter, Y. Unger and T. Strassner, ChemPhotoChem, 2017, 1, 113-115.

32 L. Zhou, P. Y. Cai, Y. Feng, J. H. Cheng, H. F. Xiang, J. Liu, D. Wu and X. G. Zhou, Anal. Chim. Acta, 2012, 735, 96-106.

33 X. F. Ma, J. H. Cheng, J. Y. Liu, X. G. Zhou and H. F. Xiang, New J. Chem., 2015, 39, 492.

34 J. H. Cheng, K. Y. Wei, X. F. Ma, X. G. Zhou and H. F. Xiang, J. Phys. Chem. C, 2013, 117, 16552-16563.

35 J. H. Cheng, Y. H. Zhang, X. F. Ma, X. G. Zhou and H. F. Xiang, Chem. Commun., 2013, 49, 11791-11793.

36 J. H. Cheng, Y. X. Li, R. Sun, J. Y. Liu, F. Gou, X. G. Zhou, H. F. Xiang and J. Liu, J. Mater. Chem. C, 2015, 3, 11099-11110.

37 X. H. Zhang, J. Shi, G. Y. Shen, F. Gou, J. H. Cheng, X. G. Zhou and H. F. Xiang, Mater. Chem. Front., 2017, 1, 1041-1050.

38 G. Y. Shen, F. Gou, J. H. Cheng, X. H. Zhang, X. G. Zhou and H. F. Xiang, RSC Adv., 2017, 7, 40640-40649.

39 J. H. Cheng, X. F. Ma, Y. H. Zhang, J. Y. Liu, X. G. Zhou and H. F. Xiang, Inorg. Chem., 2014, 53, 3210-3219.

40 J. H. Cheng, F. Gou, X. H. Zhang, G. Y. Shen, X. G. Zhou and H. F. Xiang, Inorg. Chem., 2016, 55, 9221-9229.

41 D. A. Atwood and M. J. Harvey, Chem. Rev., 2001, 101, 37-52. 42 P. G. Cozzi, Chem. Soc. Rev., 2004, 33, 410-421.

43 E. Lamour, S. Routier, J. L. Bernier, J. P. Catteau, C. Bailly and H. Vezin, J. Am. Chem. Soc., 1999, 121, 1862-1869.

44 P. Wu, D. L. Ma, C. H. Leung, S. C. Yan, N. Y. Zhu, R. Abagyan and C. M. Che, Chem. - Eur. J., 2009, 15, 13008-13021.

45 H. Miyasaka, A. Saitoh and S. Abe, Coord. Chem. Rev., 2007, 251, 2622-2664.

46 M. Andruh, Chem. Commun., 2011, 47, 3025-3042.

47 S. J. Wezenberg, E. C. Escudero-Adán, J. Benet-Buchholz and A. W. Kleij, Chem. - Eur. J., 2009, 15, 5695-5700.

48 G. Consiglio, S. Failla, P. Finocchiaro, I. P. Oliveri, R. Purrello and S. Di Bella, Inorg. Chem., 2010, 49, 5134-5142. 
49 Y. Hai, J. J. Chen, P. Zhao, H. Lv, Y. Yu, P. Xu and J. L. Zhang, Chem. Commun., 2011, 47, 2435-2437.

50 H. Y. Yin, J. Tang and J. L. Zhang, Eur. J. Inorg. Chem., 2017, 5085-5093.

51 P. F. Wang, Z. R. Hong, Z. Y. Xie, S. W. Tong, O. Y. Wong, C. S. Lee, N. B. Wong, L. S. Hung and S. T. Lee, Chem. Commun., 2003, 1664-1665.

52 C. M. Che, S. C. Chan, H. F. Xiang, M. C. W. Chan, Y. Liu and Y. Wang, Chem. Commun., 2004, 1484-1845.

53 H. F. Xiang, S. C. Chan, K. K. Y. Wu, C. M. Che and P. T. Lai, Chem. Commun., 2005, 1408-1410.

54 C. M. Che, C. C. Kwok, S. W. Lai, A. F. Rausch, W. J. Finkenzeller, N. Y. Zhu and H. Yersin, Chem. - Eur. J., 2010, 16, 233-247.

55 J. Zhang, F. C. Zhao, X. J. Zhu, W. K. Wong, D. G. Ma and W. Y. Wong, J. Mater. Chem., 2012, 22, 16448-16457.

56 N. Komiya, T. Muraoka, M. Iida, M. Miyanaga, K. Takahashi and T. Naota, J. Am. Chem. Soc., 2011, 133, 16054-16061.

57 S. J. Liu, H. B. Sun, Y. Ma, S. G. Ye, X. M. Liu, X. H. Zhou, X. Mou, L. H. Wang, Q. Zhao and W. Huang, J. Mater. Chem., 2012, 22, 22167-22173.

58 F. Gou, J. H. Cheng, X. H. Zhang, G. Y. Shen, X. G. Zhou and H. F. Xiang, Eur. J. Inorg. Chem., 2016, 4862-4866.

59 J. Brooks, Y. Babayan, S. Lamansky, P. I. Djurovich, I. Tsyba, R. Bau and M. E. Thompson, Inorg. Chem., 2002, 41, 3055-3066.

60 L. Pu, Chem. Rev., 2004, 104, 1687-1716.

61 L. Pu, Acc. Chem. Res., 2017, 50, 1032-1040.

62 E. M. Sanchez-Carnerero, A. R. Agarrabeitia, F. Moreno, B. L. Maroto, G. Muller, M. J. Ortiz and S. de la Moya, Chem.Eur. J., 2015, 21, 13488-13500.
63 J. T. Song, M. Wang, X. G. Zhou and H. F. Xiang, Chem. Eur. J., 2018, 24, 7128-7132.

64 C. Garino, A. Erenzi, G. Barone and L. Salassa, J. Chem. Educ., 2016, 93, 292-298.

65 J. S. Ni, H. X. Liu, J. K. Liu, M. J. Jiang, Z. Zhao, Y. C. Chen, R. T. K. Kwok, J. W. Y. Lam, Q. Peng and B. Z. Tang, Mater. Chem. Front., 2018, 2, 1498-1507.

66 G. X. Huang, R. S. Wen, Z. M. Wang, B. S. Li and B. Z. Tang, Mater. Chem. Front., 2018, 2, 1884-1892.

67 H. Nie, K. Hu, Y. J. Cai, Q. Peng, Z. J. Zhao, R. R. Hu, J. W. Chen, S. J. Su, A. J. Qin and B. Z. Tang, Mater. Chem. Front., 2017, 1, 1125-1129.

68 M. Yamaguchi, S. Ito, A. Hirose, K. Tanaka and Y. Chujo, Mater. Chem. Front., 2017, 1, 1573-1579.

69 M. Wang, C. Cheng, J. T. Song, J. Wang, X. G. Zhou, H. F. Xiang and J. Liu, Chin. J. Chem., 2018, 36, 698-707.

70 E. V. Puttock, M. T. Walden and J. A. G. Williams, Coord. Chem. Rev., 2018, 367, 127-162.

71 G. Z. Lu, Y. M. Jing, H. B. Han, Y. L. Fang and Y. X. Zheng, Organometallics, 2017, 36, 448-454.

72 Y. Tao, K. Yuan, T. Chen, P. Xu, H. H. Li, R. F. Chen, C. Zheng, L. Zhang and W. Huang, Adv. Mater., 2014, 26, 7931-7958.

73 Z. Y. Yang, Z. Mao, Z. L. Xie, Y. Zhang, S. W. Liu, J. Zhao, J. R. Xu, Z. G. Chi and M. P. Aldred, Chem. Soc. Rev., 2017, 46, 915-1016.

74 M. Y. Wong and E. Zysman-Colman, Adv. Mater., 2017, 29, 1605444. 